\title{
OROSIRIAN CALC-ALKALINE VOLCANISM AND THE OROCAIMA EVENT IN THE NORTHERN AMAZÔNIAN CRATON, EASTERN RORAIMA STATE, BRAZIL
}

\author{
NELSON JOAQUIM REIS ${ }^{1}$, MARIO SÉRGIO GOMES DE FARIA ${ }^{1}$, LEDA MARIA FRAGA ${ }^{1}$ \\ AND REGINA CLÉLIA HADDAD ${ }^{2}$
}

\begin{abstract}
In the eastern portion of the Brazilian state of Roraima there are two main volcanic terranes of Paleoproterozoic age: the Surumu Group to the north and the Iricoumé Group to the south. The Central Guyana Belt is located between these groups. Geochemical and geochronological data point to a dissociation with the anorogenic granitoids related to Saracura and Mapuera suites, presently grouped into the Uatuma Supergroup (Uatumã Event, 1.90-1.70Ga). Chemical characteristics of volcanic rocks are very similar to those observed in the calcalkaline granitoids such as the Pedra Pintada and Agua Branca suites (1.96-1.91Ga) pointing to a post-collisional setting, related to the end of Trans-Amazônian Orogeny. The Surumu Group is usually metamorphosed in the lower greenschist facies, with steep foliation and open folding The Surumu - Iricoumé groups represent a series of acidic to intermediate volcanics, metaluminous and calc-alkaline affinities, similar to those observed in modern magmatic arcs. The REE pattern shows two characteristic groups of volcanics, suggesting distinctive magmatic evolution. Both volcanic-plutonic associated Surumu - Pedra Pintada and Iricoumé - Água Branca and previous molassic sedimentary covers show a new geological framework and are postulated to the Orocaima Event $(1.98-1.88 \mathrm{Ga})$, Orosirian Period.
\end{abstract}

Keywords: Calc-alkaline volcanism, Orocaima Event, Geochemistry, Geochronology, Orosirian, Paleoproterozoic, Guiana Shield, Amazônian Craton, Roraima State, Brazil

INTRODUCTION The name "Uatumã" was formerly used to designate volcanic rocks from north and south areas of the Amazonas Basin. In the seventies, large $\mathrm{Rb}-\mathrm{Sr}$ isotope data were used to propose the timing between volcanic and overlying sedimentary rocks and related basic intrusives, within the range of 1.90-1.70 Ga (Basei \& Teixeira 1975). Melo et al. (1978) reported the existence of shallow granitic bodies (Saracura Suite) and intruding volcanics, proposing a comagmatic process at their genesis. Other studies (e.g. Costi et al. 1984) have grouped volcanic rocks to the south under the name "Iricoumé", correlating to Surumu Group in the northern part of the state of Roraima (Fig. 1). Gibbs \& Barren (1993), despite showing the scarcity of sedimentary intercalations into the sequence, included sedimentary rocks from the Muruwa Formation (Guyana) into the Uatumã Supergroup.

Throughout the Guiana Shield, the Surumu and Iricoumé volcanics correlate with Cuchivero and Pacaraima groups from Venezuela, in Surinam with the Dalbana Formation and in Guyana the Burro-Burro Group (Iwokrama Formation) to the north and the Kuyuwini Group to the south.

Recent studies from Reis \& Fraga (1996) and Reis et al. (1999) have demonstrated a comagmatic relation between the Surumu Iricoumé. volcanism and the Pedra Pintada (Fraga et al. 1996) - Água Branca (Oliveira et al. 1996) I-type granitoids. A zircon U-Pb age of $1962 \pm 42$ Ma by Schobbenhaus et al. (1994) from a Surumu sample, reinforces an older chronostratigraphic framework for volcanism more compatible with the chemical characteristics between Surumu volcanics and Pedra Pintada granitoids (Reis \& Fraga 1996). Santos (1999) obtained two zircon U-Pb (SHRIMP) ages of $1984 \pm 7$ Ma and $1977 \pm 8 \mathrm{Ma}$ from Surumu volcanics, thus suggesting an age difference between Surumu volcanism and Pedra Pintada granitoids of approximately $25 \mathrm{Ma}$. The latter indicates a U-Pb (SHRIMP) age of $1958 \pm 11 \mathrm{Ma}$ (Santos 1999) and $\mathrm{Pb}-\mathrm{Pb}$ age of $2005 \pm 45 \mathrm{Ma}$ (Almeida et al. 1997). To the south, Santos (1999) obtained a zircon U-Pb (SHRIMP) age of $1896 \pm 7 \mathrm{Ma}$ from Iricoumé rocks. In this same region, Almeida et al. (1997) pointed to an $\mathrm{Pb}-\mathrm{Pb}$ age of $1938 \pm$

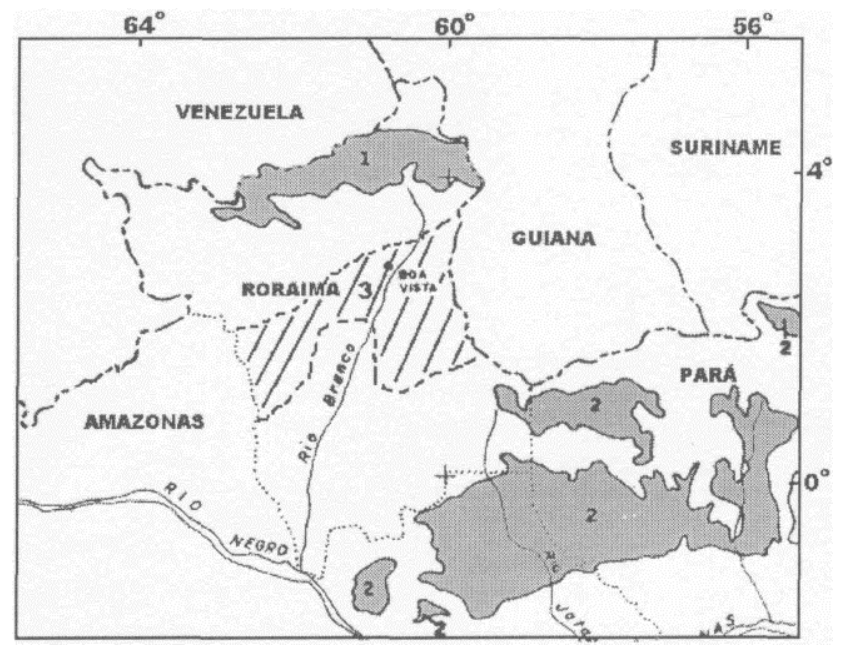

Figure 1 - Distribution of volcanic rocks from Surumu Group (I) and Iricoumé Group (2) in relation to Central Guiana Belt (3).

Table 1 -Ages of post-tectonic granitoids and volcanics from eastern Roraima State.

\begin{tabular}{|ccccc|}
\hline Locallity & Method & Age (Ma) & Unit & Reference \\
\hline Km 164/BR-174 & U-Pb (SHRIMP) & $1896 \pm 7$ & Iricoumé Group & Santos (1999) \\
NW Pará State & Rp-Sr & $1910 \pm 47$ & Água Branca Suite & Jorge João et al. (1985) \\
Anauá Mine & Pb-Pb & $1938 \pm 37$ & Igarapé Azul Granite & Almeida et. al. (1997) \\
- & Rb-Sr (isochron) & 1951 & Água Branca Suite & Santos \& Reis Neto (1982) \\
Orocaima Mt. & U-Pb (SHRIMP) & $1958 \pm 11$ & Pedra Pintada Suite & Santos (1999) \\
Rorainópolis & Pb-Pb & $1960 \pm 21$ & Igarapé Azul Granite & Almeida et. al. (1997) \\
Tabaco Mt. & U-Pb & $1962 \pm 42$ & Surumu Group & Schobbenhaus et al. (1994) \\
Saracura Mt. & U-Pb (SHRIMP) & $1977 \pm 8$ & Surumu Group & Santos (1999) \\
Urarucaá River & U-Pb (SHRIMP) & $1984 \pm 7$ & Surumu Group & Santos (1999) \\
Pedra Pintada & Pb-Pb & $2005 \pm 45$ & Pedra Pintada Suite & Almeida et. al. (1997) \\
\hline
\end{tabular}

1 - CPRM - Serviço Geológico do Brasil - Manaus-AM - Av. André Araújo 2160, Aleixo, CEP: 69.060-001 Manaus-AM, Brasil - Fax: (92) 663-5531 e-mail: geride@internext.com.br

2 - Departamento de Geociências - Universidade do Amazonas - Av. Gal. Rodrigo O.J. Ramos 3000 - Campus Universitário - CEP: 69.077-000 Manaus-AM, Brasil - Fax: (92) 644-1510/644-2227 
37 Ma and $1960 \pm 21$ Ma from granitoids named "Igarapé Azul" (Faria et al. 1999). Geochronological data are given in Table 1 and present the available ages from post-tectonic granites and volcanics from the eastern portion of Roraima State.

PETROGRAPHY Wherever volcanic rocks of Surumu and Iricoumé groups outcrop, they present a small range of effusive and pyroclastic varieties. The most common type is dacite, with a small proportion of andesites and subordinated rhyolites. The felsic nature also prevails in pyroclastic rocks. The volcanics are often foliated, relating to a deformational processes on a ductile - brittle framework associated with the K'Mudku Event.

The commonest type of dacite shows a porphyritic texture, with abundant phenocrysts of plagioclase in a matrix of quartz, plagioclase, alkaline feldspar, biotite and hornblende. Opaques, apatite, zircon and titanite are common accessories. Sericite, chlorite, epidote and carbonate are secondary minerals. The rhyolites show porphyritic to glomeroporphyritic texture in relation to dacites, with microcline and quartz phenocrysts over plagioclase. Recrystallized quartz aggregates are common in the matrix, which still shows a minor mafic minerals content (biotite and hornblende), the presence of allanite, but no evidence of carbonate.

The andesite has minor phenocrysts (plagioclase and rare amphibole) in a microcrystalline matrix of plagioclase, amphibole and biotite with abundant secondary sericite and chlorite. Quartz, opaques, apatite and rare titanite are accessories. Late saussuritization and serialization of the plagioclase are always accompanied by replacement of the amphibole with opaque \pm chlorite \pm epidote. Biotite is always chloritized. Sulfides are locally disseminated.

The mylonites consist largely of andesitic, dacitic and rhyolitic rocks submitted to intense shearing. The groundmass texture is porphyroclastic in a fine matrix characterized by development of a greenschist metamorphic paragenesis through the sericitization of feldspar, saussuritization of plagioclase, recrystallization of quartz, chloritization of biotite and amphibole.

GEOCHEMISTRY The volcanic rocks show $\mathrm{SiO}_{2}$ ranging from $54,1 \%$ to $72,5 \%$, mg\# from 13,40 to 49,93 and $\mathrm{Na}_{2} \mathrm{O} / \mathrm{K}_{2} \mathrm{O}$ ratios from 0.50 to 1.81 (geochemical results can be obtained from the authors of this article).

In the TAS (silica versus total alkalis) diagram (Le Maitre et al. 1989, Fig. 2a) the metaluminous volcanic rocks plot on rhyolite, dacite, trachydacite, andesite, trachyandesite and a basaltic andesite field. A relative $\mathrm{K}_{2} \mathrm{O}$ enrichment in the acid members is related to high-K series (Le Maitre et al. 1989, Fig. 2b). It also shows enrichment in $\mathrm{Cr}, \mathrm{Ni}, \mathrm{Rb}, \mathrm{Zr}$ and $\mathrm{Ba}$ compared to calc-alkaline types from literature.

Chondrite-normalized REE patterns (Sun 1982) support the distinction of two geochemical groups, both indicating distinctive magmatic evolution. The first one exhibits a relatively fractionated

A

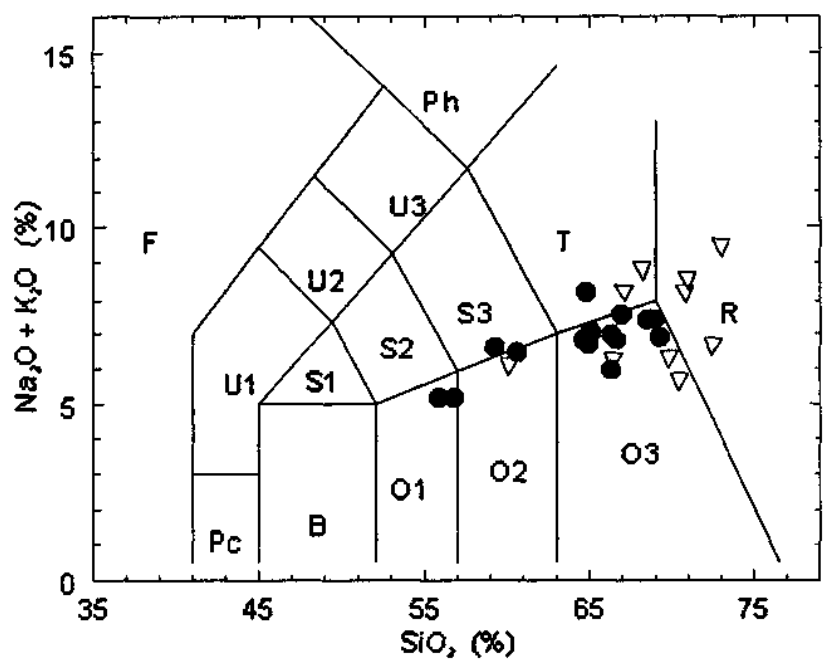

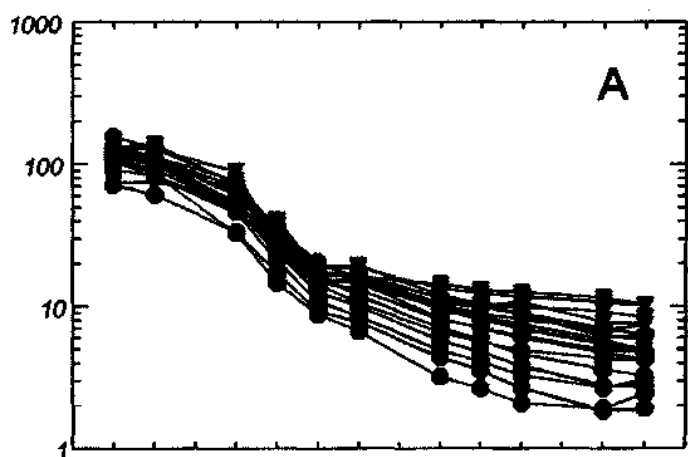

Le Ce Pr Nd SmEu Gd Tb Dy Ho Er Tm Yb Lu
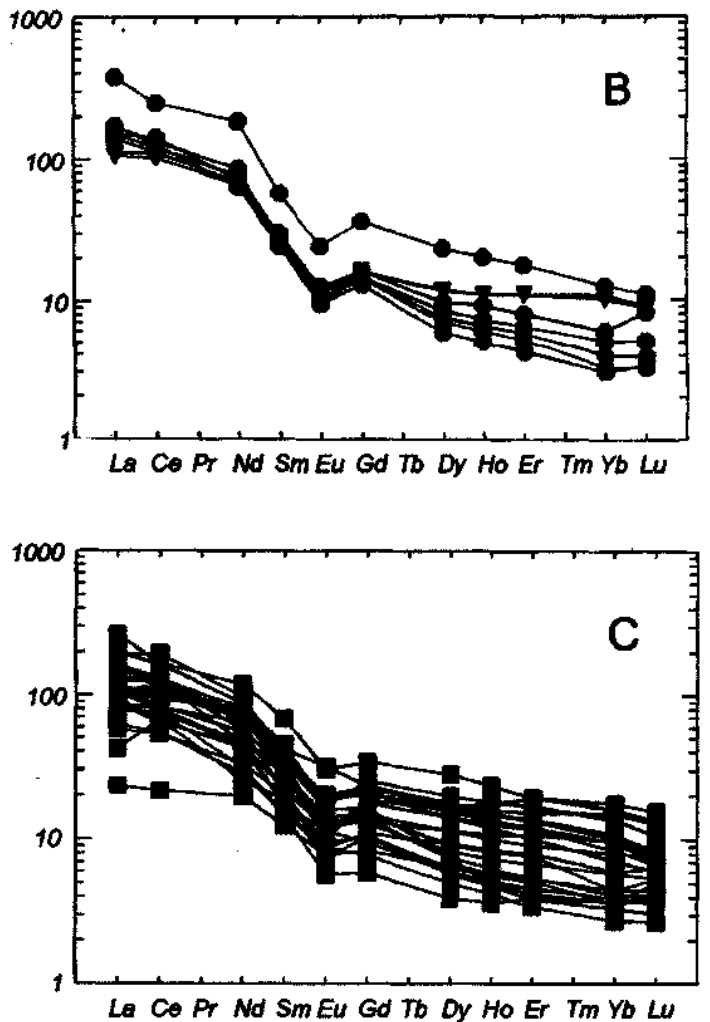

Figures 3 - Chondrite normalized REE patterns: $a$ - (1 and 2) of the Surumu Group; $b$ - Iricoumé Group. Normalizing values are from Sun (1982). Symbols as in Figure 2; c - of the calc-alkaline Pedra Pintada and Água Branca suites. Normalizing values are from Sun (1982).

B

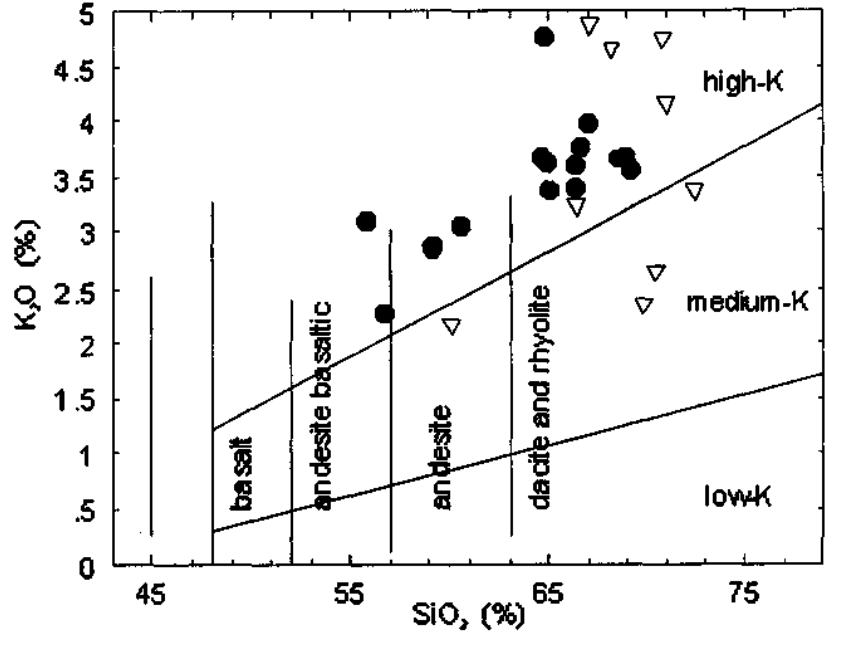

Figure 2- a - TAS diagram (Le Maitre et al. 1989) for Surumu Group (triangles) and Iricoumé Group (full circles). Keys: $R$ - Rhyolite; $T$ - Trachyte; O3 Dacite; $\mathrm{O} 2$ - Andesite; $\mathrm{S} 3$ - Trachyandesite; $\mathrm{O} 1$ - Basaltic Andesite. $b-\mathrm{SiO}_{2}$ versus $\mathrm{K}_{2} \mathrm{O}$ diagram (Le Maitre et al. 1989). 

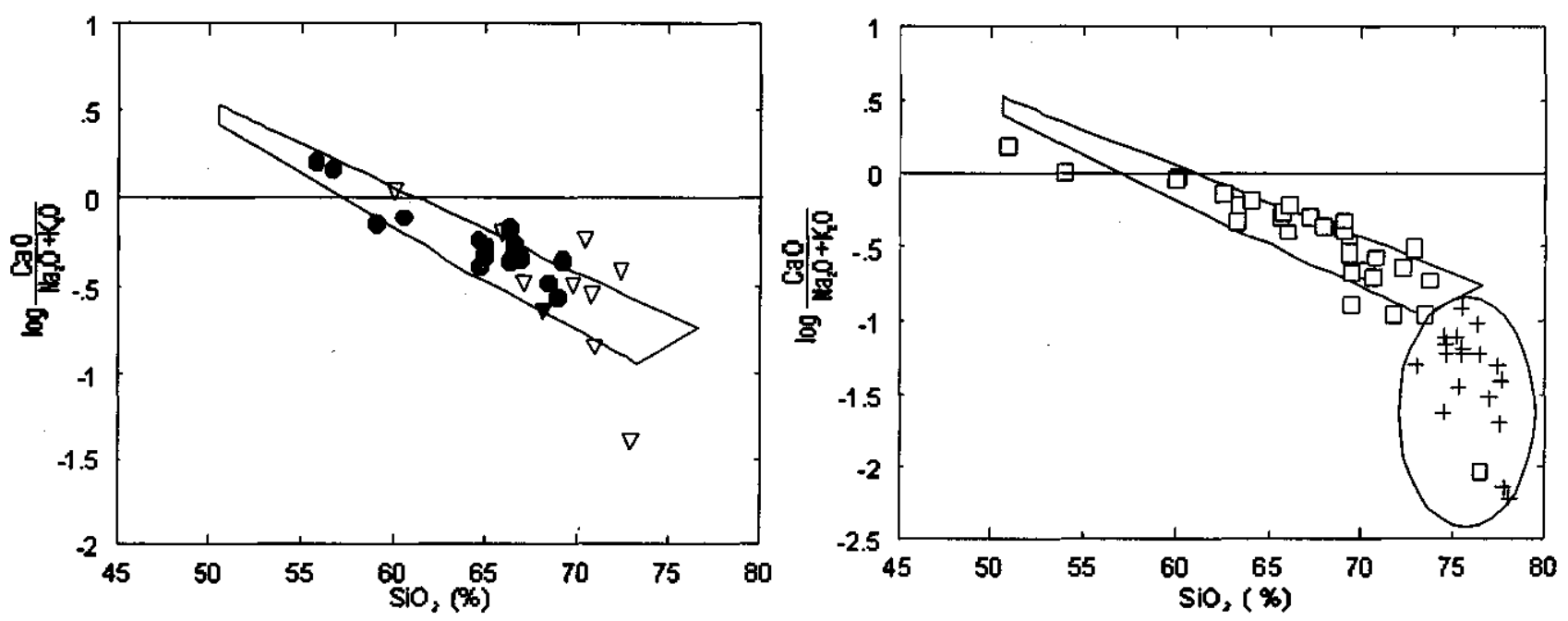

Figures 4 - Brown et al. (1984) diagram showing distribution field for modern magmatic arc calc-alkaline volcanics. Volcanic rocks from Surumu - Iricoumé groups (symbols as in Figure 2), and Pedra Pintado - Agua Branca suites (squares) and Saracura - Mapuera suites (crosses).

pattern and a negative Eu anomaly, LREE enrichment and HREE depletion (Fig. 3a). This group is characterized by mafic phase dominated fractionation. The other exhibits moderate negative Eu anomaly, clear LREE fractionation and undifferentiated patterns of MREE and HREE (Fig. 3b). The presence of negative Eu anomalies favors the major or minor presence of plagioclase in order to explain a fractionated or residual phase in the parental magma generation of the volcanic rocks and accompanying mafic phases with added HREE and/or MREE (clinopyroxene and/or amphibole).

Both Surumu - Iricoumé REE patterns are similar to those observed in the different petrographic groups of Pedra Pintada and Agua Branca suites (Fig. 3c).

According to Brown et al. (1984) (Fig. 4), they also present greater distribution in the calc-alkaline volcanic field than modern magmatic arc, showing similarities with the plot of calc-alkaline granitoids of Pedra Pintada (Fraga et al. 1997b) and Água Branca suite, in contrast with the anorogenic Saracura and Mapuera suites (Fig. 4).

DISCUSSION Apart from some continents with erogenic episodes within the range 1.95-1.80 Ga, the Trans-Amazônian Cycle constitutes an important event with strong metamorphism, deformation and intrusion in the Amazônian Craton around 2.20 - $2.00 \mathrm{Ga}$. The end of the cycle was broadly defined by the presence of post-tectonic calcalkaline plutonism with moderate deformation. In Roraima State the picture is similar, including the Pedra Pintada and Água Branca suites. Both units show ages within the range 2.00-1.91 Ga (Santos \& Reis Neto 1982, Jorge João et al. 1985, Almeida et al. 1997, Santos 1999). Of particular interest to the understanding of the framework of the shield is the transitional timing between the erogenic and cratonic domains, displayed by intense volcanism, plutonism and sedimentation. In Roraima State, this transitional domain indicates ages older than the 1.8-1.6 Ga interval from other known shields. Recent isotopic values for Surumu rocks at 1.98-1.96 Ga interval (Schobbenhaus et al. 1994, Santos 1999) plus geochemical studies carried on by Reis \& Fraga (1996) and Reis et al. (1999) have established temporal and chemical affinities with Pedra Pintada - Água Branca granitogenesis. The latter authors have also pointed out chemical data contrasting entirely with anorogenic types like Saracura and Mapuera suites, which are actually postulated for the Uatuma Event.

Dall'Agnol et al. (1987) reports that the calc-alkaline volcanism shows a significant amount of dacitic and andesitic terms, concluding that there is no genetic link with typically anorogenic granites, being truly alkaline and without significant associated intermediate rocks. In contrast, some interpretations have been put forward for an anorogenic character of the acid magmatism, such as a deep angular unconformity between the greenstone and volcanic rocks, in addition to their different structural style (Gibbs \& Barren 1993).

In the Guiana Shield there are several sedimentary sequences of shallow water origin, resting conformably under volcanic rocks related to Uatuma, sometimes interdigitated with the first manifestation of volcanism (Gibbs \& Barren 1993), but this phenomenon have not yet been reported by the Brazilian counterpart. Some correlated units are known, such as Los Caribes Formation in Venezuela, Muruwa Formation in Guyana and Ston Formation in Suriname, which point to a molasse sedimentation contemporaneous with Paleoproterozoic volcanism and plutonism. They may constitute successor basins (Ingersoll 1988), with limited associated volcanism and moderate deformation, indicating the end of the orogenic activity, forming primarily in intermontane settings, on top of inactive fold-thrust belts or failed rifts.

Santos (1978) took the available geochronological data from the seventies and established the time line between the Lower and Middle Proterozoic, taking into account the initial phase of Uatuma volcanism $(1.90 \mathrm{Ga})$ and dissociating the whole magmatism from the TransAmazônian Orogenic Cycle. In Suriname, Bosma et al. (1983) noted that the Trans-Amazônian should be regarded as having taken place in two stages, a first one deformational and metamorphic, around $2.0 \mathrm{Ga}$, and the other, essentially magmatic, around $1.87 \mathrm{Ga}$.

The truly terminal phase is represented by more extensive platform cover in previously cratonized orogenic areas, for example, Roraima Supergroup (Pinheiro et al. 1990), whose minimum depositional age was established at $1.77 \mathrm{Ga}$ (Santos 1999) in dykes and sills related to Avanavero Diabase.

The geochronological data also favor a close relationship in space and time between the generation of Surumu magmatism, Pedra Pintada - Água Branca plutonism and the development of the Central Guiana Belt (CGB). At CGB, the orthogneisses show ages within a $1.96-1.91$ Ga range (Santos \& Olszewski 1988, Gaudette et al. 1996, Fraga et al. 1997a). To the north, outside the CGB, the Surumu and Pedra Pintada rocks show a deformational pattern printed along the shear zones. This feature, especially printed in volcanic rocks, is absent in the Roraima basin. In turn, Gibbs \& Barron (1993) report the presence of open folds in volcanic rocks, recording a Post-Trans-Amazônian compressive deformational episode. According to the authors, the sedimentary rocks from Roraima Supergroup rest in unconformity over the previously deformed volcanic rocks.

A chemical relationship toward a comagmatism between Surumu Iricoumé groups and Pedra Pintada - Agua Branca suites, new geochronological data and structural framework, favor a review of the terminology "Uatuma Supergroup" and "Uatuma Event" in the sense of a volcano-plutonic association with eminent anorogenic character.

Accordingly, the designation "Orocaima Event" is proposed here to demonstrate a major event of calc-alkaline volcano-plutonism, related to the Orosirian Period, of a broad area from Guiana Shield. At Roraima State, the type-area is defined along the Orocaima Mountains, some few kilometers to the northwest from the occurrence of Pedra Pintada granitoids and Surumu volcanics (about $3^{\circ} 40^{\prime}$ and $4^{\circ} 20^{\prime} \mathrm{N}$; $60^{\circ} 50^{\prime}$ and $61^{\circ} 15^{\prime} \mathrm{W}$ ). This same assemblage is reported somewhere else south of Roraima including volcanic rocks from Iricoumé Group 
and granitoids from Água Branca Suite. Emphasized in this paper are the common chemical characteristics and development timing shared by those units, which together provide a new and interesting picture of the evolutionary framework of Orosirian rocks from Guiana Shield.

FINAL CONSIDERATIONS The pionosed Orocaima Event represents \pm 100 Ma volcano-plutonism (1.98-1.88 Ga) as supported from investigations in Surumu - Iricoumé volcanic rocks and Pedra Pintada - Água Branca granitic rocks from Roraima State, with a similar picture emerging in neighboring countries (Venezuela - VE, Guyana - GU and Suriname - SU). It also includes the sedimentary rocks from Los Caribes (VE), Muruwa (GU) and Ston (SU) formations, which suggest successor basins in intermontane settings;

The available isotopic ages for volcanic rocks suggest younger values toward the southem portion of Amazonian Craton (Iriri Group);

The Central Guyana Belt constitutes a broad area of exposure of Paleoproterozoic (1.96-1.91 Ga) high-grade rocks, in which timing is nearly concordant with that of Orocaima Event to the north and to the south of the belt;

A relatively short time interval between the molassic sedimentation of Los Caribes - Muruwa - Ston basin, calc-alkaline volcanoplutonism and development of the Central Guyana Belt (although of great complexity), points to a temporal association related to the last stages of the Trans-Amazônian Cycle. It follows an anorogenic tectonic environment with plutonism, platform cover and basic magmatism (1.86-1.77 Ga) (e.g., Saracura and Mapuera suite; Roraima Supergroup and Urupi Formation; Avanavero and Quarenta Ilhas Diabase);

REE pattern from volcanics point to two distinctive groups of rocks, suggesting different magmatic evolutions. It shows similarities with different petrographic groups from the calc-alkaline Pedra Pintada and Água Branca suite and probably involved mantle derived magma associated with crustal ones.

\section{References}

Almeida M.E. Fraga L.M.B., Macambira M.J.B. 1997. New Geochronological Data of Calc-alkaline Granitoids of Roraima State, Brazil. In: South-American Symposium Calc-alkaline Granitoids of Roraima State, Brazil. In: Sout

Basel M.A.S. \& Teixeira W. 1975. Geocronologia do Território de Roraima. In: DNPM, Conferencia Geológica Interguianas, 10, Bel'ém, Anais, 453-473.

Bosma W., Korrnenberg S.B., Maas K., DeRoever E.W.F. 1983. Igneous and Metamorphic Complexes of the Guiana Shield in Suriname. Geologic en Mijnbouw, 62:241-254.

Brown G.C., Thorpe R.S., Webb P.C. 1984. The Geochemical Characteristics of Granitoids in Contrasting Arcs and Comments on Source Magmas. Journal Geology Society of London, 141:413-426.

Costi H.T., Pinheiro S.S., Santiago A.F. 1984. Projeto Uatuma-Jatapu; Relatório Final. Manaus, DNPM/C̈PRM.

Dall'Agnol R., Bettencourt J.S., Jorge Joao X.S., Medeiros H., Costi H.T., Macambira

M.J.B. 1987. Granitogenesis in Northern Brazilian Region: A Review. Revista Bra-

sileira de Geociências, 17:382-403.

Faria M.S.G., Luzardo R., Pinheiro S.S., silva L.C. 1999. Litoquimica e Petrogênese do Granito Igarapé Azul, Sudeste de Roraima. In: SBG/Nucleo Norte Simpósio de Geologia da Amazônia, 6, Manaus, Resumos Expandidos, 577-580.

Fraga L.M.B., Reis N.J., Araujo R.V., Haddad R.C. 19\%. Suite Intrusiva Pedra Pintada Um Registro do Magmatismo P6s-colisional no Estado de Roraima. In: SBG/Nucleo Norte Simpósio de Geologia da Amazônia, 5, Belem, Anais,76-l\%

Fraga L.M.B., Almeida M.E., Macambira M.J.B. 1997a. First Lead-Lead Zircon Ages of Charnockitic Rocks from Central Guiana Belt (CGB) in the State of Roraima, Brazil. In: South-American Symposium on Isotope Geology, Campos do Jordão, Resumo, In: South-

Fraga L.M.B., Haddad R.C., Reis N.J. 1997b. Aspectos Geoquímicos das Rochas Granitóides da Suite Intrusiva Pedra Pintada, Norte do Estado de Roraima. Revista Brasileira de Geociências, 27:3-12.

Gaudette H.E., Olszewski Jr. W.J., Santos J.O.S. 1996. Geochronology of Precambrian Rocks from the Northern Part of Guiana Shield, State of Roraima, Brazil. Journal of South American Earth Sciences, 9:183-195

Gibbs A.K. \& Barren C.N. 1993. The Geology of the Guiana Shield. New York, Claredon Press, Oxford, $245 \mathrm{p}$.

Ingersoll R. V. 1988. Tectonics of Sedimentary Basins. Geological Society of America Bulletin, 100:1704-1719.

Jorge Joao X.S., Santos C.A., Provost A. 1985. Magmatismo Adamelítico Á gua Branca (Folha Rio Mapuera, NW do Estado do Pará). In: SBG, Simpósio de Geologia da Amazônia, 2, Belem, Anais, 2:93-109. Le Maitre R.W., Bateman P., Dudex A., Keller J., Lameyre Le Bas M.J., Sabine P.A.,
Schmid R., Sorensen H., Streckeisen A., Wooley A.R., Zanettin B. 1989. A Schmid R., Sorensen H., Streckeisen A., Wooley A.R., Zanettin B. 1989.

Classification of Igneous Rocks and Glossary of Terms. London, Edinburgh, $193 \mathrm{p}$.
Melo A.F.F., Santos A.J., Cunha M.T.P., Campos M.J., d'Antona R.J.G. 1978. Projeto Molibdenio em Roraima; Relatório Final. Manaus. DNPM/CPRM, v. I-A e B. il.

Oliveira M.J.R., Almeida M.E., Luzardo R., Faria M.S.G. 1996. Litogeoquímica da Sufte Intrusiva Agua Branca - SE de Roraima. In: SBG, Congresso Brasileiro de Geologia, 39, Salvador Anais, 2:213-216

Pinheiro S.S., Reis N.J., Costi H.T. 1990. Geologia da Região do Caburai, Estado de Roraima. Relatório Final. Manaus, DNPM/CPRM, $91 \mathrm{p}$.

Reis N.J. \& Fraga L.M.B. 1996. Vulcanismo Surumu- Estado de Roraima: Caracterização de seu comportamento quimico a luz de novos dados. In: SBG, Congresso Brasileiro de Geologia, 38, Salvador Anais, 2: 88-90.

Reis N.J., Faria M.S.G., Haddad R.C., Fraga L.M.B. 1999. Vulcanismo Calci-Alcalino Paleoproterozdico do Setor Oriental do Estado de Roraima. In: SBG, Simpósio de Vulcanismo e Ambientes Associados, 1, Gramado, Resumos Expandidos, 78.

Santos J.O.S. 1978. Subdivisão do Pré-Cambriano da Amazônia: uma sugestão. Acta Amazonica. 8:267-287.

Santos J.O.S. \& Reis Neto J.M. 1982. Algumas Idades de Rochas Graniticas do Craton Amazônico. In: SBG, Congresso Brasileiro de Geologia, 32, Salvador Anais, 1:339348 .

Santos J.O.S. \& Olszewski W. 1988. Idade dos granulitos tipo Kanuku em Roraima. In: SBG/DNPM, Congresso Latinoamericano de Geologia, 7, Belem Anais, 378-388

Santos J.O.S. 1999. New understanding of the Amazon Craton Gold Provinces. In: New Developments in Economic Geology. Center for Teaching and Research in Strategic Developments in Economic Geology. Center for Teaching and Re
Mineral Deposits. University of Western Australia, Perth, $10 \mathrm{p}$.

Schobbenhaus C., Hoppe A., Lork A., Baumann A. 1994. Idade U/Pb do magmatismo UatumS no norte do Ciiton Amazonico, Escudo das Guianas (Brasil): primeiros resultados. In: SBG, Congresso Brasileiro de Geológia, 37, Camboriu, Anais, 2:395 397.

Sun S.S. 1982. Chemical Composition and Origin of the Earth's Primitive Mantle. Geoch. Cosmoch. Acta, 46:179-182.

Contribution IGC-021

Received January 26,2000

Accepted for publication May 22,2000 